\title{
WHAT IS YOUR DIAGNOSIS?
}

\section{Case for diagnosis}

Caso para diagnóstico

Marcelo Campos Appel da Silva ${ }^{1}$ Claudio Galeano Zettler ${ }^{3}$
Diego da Rosa Miltersteiner ${ }^{2}$

Luciana Weis ${ }^{4}$
Jayme Eduardo Burmeister ${ }^{2}$

\section{CASE REPORT}

Female patient, 48 years old, white, with chronic renal failure due to diabetic nephropathy treated with hemodialysis for 2 years. She reported recent pruritic lesions in the trunk, limbs and scalp. Physical examination revealed erythematous, papular lesions, hyperkeratotic in the central portion, some excoriated, located in the areas mentioned (Figure 1). There were also reports of new

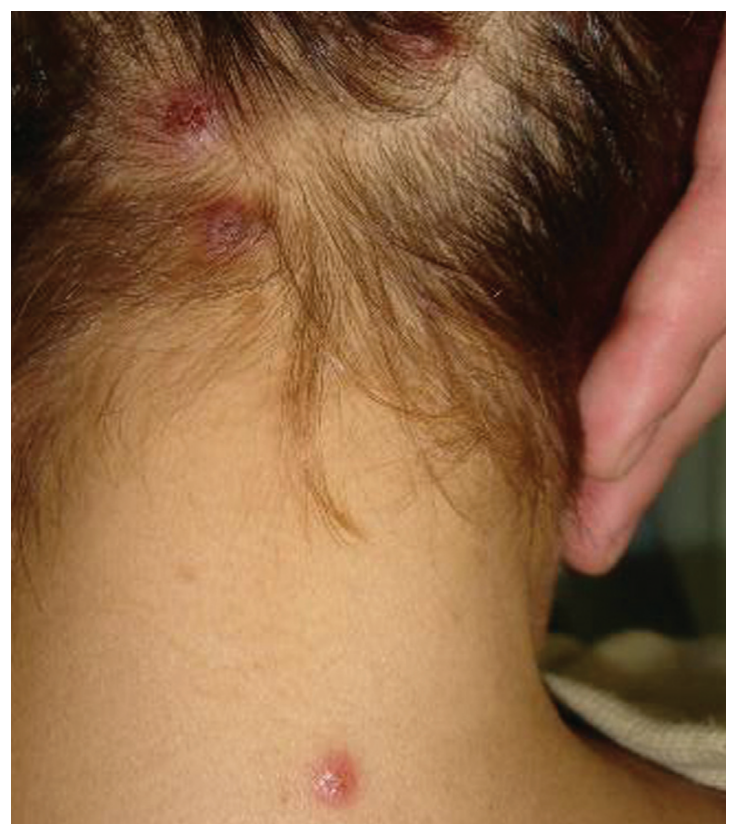

FiguRE 1: Hyperkeratotic, excoriated erythematouspapular lesions in the scalp and dorsum

IGURE 2: Histopathology stained with hematoxylin-eosin (200X magnification) showing epidermal invagination with keratotic plug and collagen fibers moving from the dermis to the epidermis lesions after scratching the skin - suggesting the occurrence of Koebner's phenomenon.

Incisional biopsy of the scalp lesion was performed. Histopathology showed epidermal invagination with keratotic plug and collagen fibers moving from the dermis to the epidermis (Figure 2) typical of perforating dermatosis.

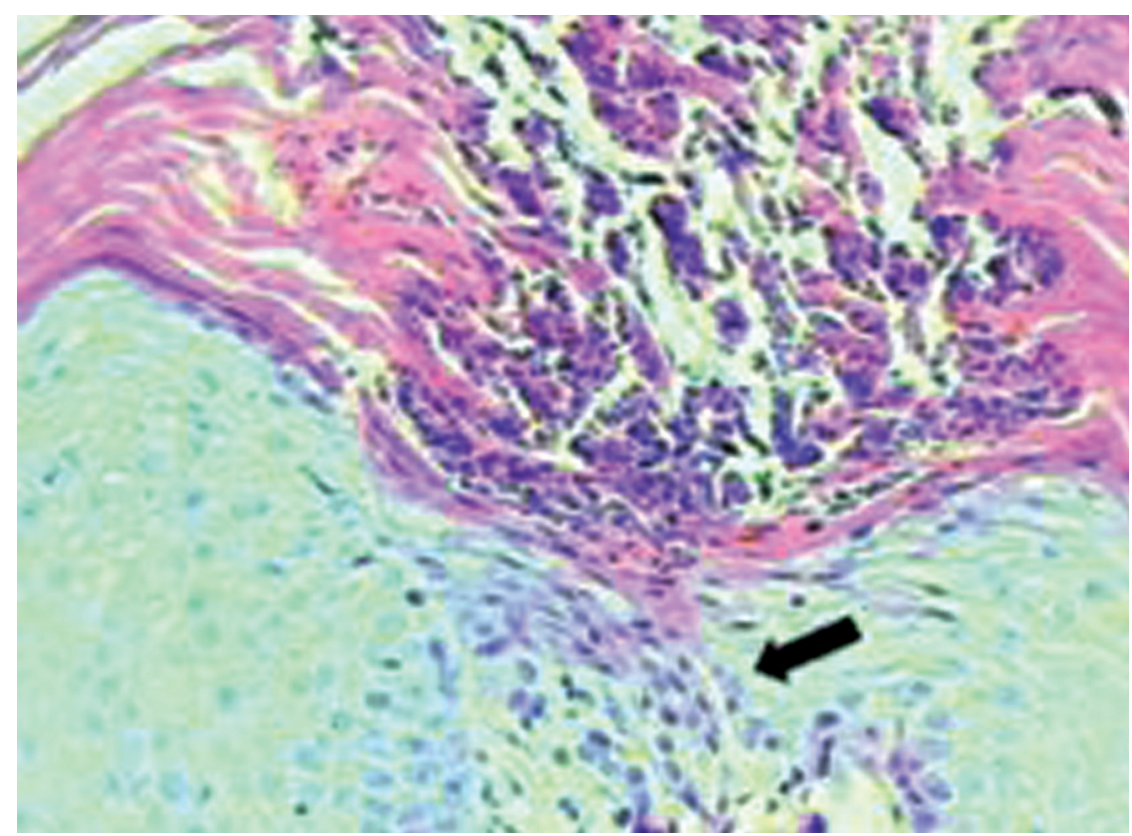

Approved by the Editorial Board and accepted for publication on 18.08.2010.

Work conducted at the Renal Medical Unit and the Pathology Service - University Hospital, Lutheran University of Brazil (HU - ULBRA) - Canoas (RS) Brazil.

Conflito de interesse: Nenhum / Conflict of interest: None
Suporte financeiro: Nenhum / Financial funding: None

MD; Specialist in Internal Medicine, Grupo Hospitalar Conceição - Porto Alegre (RS), Brazil.

Nephrologist - Professor of Medicine/Nephrology, University Hospital, Lutheran University of Brazil (ULBRA) - Canoas (RS), Brazil.

Nephrologist - Professor of Medicine/Nephrology, University Hospital, Lutheran University of Brazil (ULBRA) - Canoas (RS), Brazil.

Dermatologist - Mãe de Deus Hospital - Porto Alegre (RS), Brazil. 


\title{
What is your diagnosis?
}

\author{
Caso para diagnóstico
}

Appel da Silva MC, Miltersteiner DR, Burmeister JE, Zettler CG, Weis L

\section{DISCUSSION}

Perforating dermatoses are rare in the general population and lead to the transepithelial elimination of degenerated dermal tissue, with minimal involvement of surrounding tissues. This group of diseases can be divided into primary (represented by Kyrle's disease, perforating serpiginous elastosis, reactive perforating collagenosis and perforating folliculitis) or secondary (acquired perforating dermatosis [APD]) - associated with various comorbidities. ${ }^{1.2}$

APD was first described in association with chronic renal failure, with or without hemodialysis, and with diabetes mellitus. ${ }^{2}$ Subsequent data from the literature indicated incidence of APD in up to $11 \%$ of these patients, with lesions usually developing in adulthood. ${ }^{3}$ More recent publications have described its association with other systemic diseases such as tumors, chronic hepathopathies and HIV, among others. ${ }^{4,5}$ It is characterized by the presence of erythematous papules with a hyperkeratotic center, pruritic, mainly located in the trunk and limbs.

The pathophysiology of these lesions is still uncertain, but transdermal elimination of degenerate material is the final common pathway. In patients with diabetes and chronic renal disease one of the most thought-of hypotheses is that diabetic microangiopathy would impede wound healing; however, it has also been suggested that minor trauma such as scratching would lead to necrosis of tissues which would be eliminated through the epidermis; or also that the renal disease itself would be the main factor. ${ }^{3}$
Several therapeutical measures have been suggested, but there are no controlled, randomized clinical trials comparing the different treatment options. The use of topical high potency corticosteroids has helped to reduce inflammation and control pruritus, but it does not prevent the development of new lesions. ${ }^{1,3}$ Oral and topical preparations of retinoids, derivatives of vitamin A, cryotherapy, and keratolytic agents have all been used with varying results. 1.3 More recently, the use of ultraviolet $\mathrm{B}$ radiation has shown more promising results; in another case, the use of allopurinol, both alone and in combination with PUVA (psoralen with ultraviolet A), emerged as a new possibility. ${ }^{3}$

Our patient was investigated for other comorbidities potentially associated with APD, which were all ruled out, providing strong evidence of association with chronic nephropathy and diabetes mellitus.

The importance of diagnosing APD transcends academic motivation Considering the high prevalence of certain systemic illnesses associated with APD, especially kidney disease, this dermatosis should be considered a cutaneous marker for the possibility of chronic kidney disease.

Regular visits to the doctor are recommended for patients with chronic diseases, as they provide opportunities to assess established treatments and to review unusual symptoms. Hence, a complete physical examination should always be conducted in search of lesions that have been overlooked by the patient. A multiprofessional approach is also essential in assessing these patients, thus reducing the time to the diagnosis of complications and improving the outcome.

Abstract: Acquired perforating dermatosis is a rare condition often associated with some systemic diseases, especially diabetic patients with chronic renal failure undergoing dialysis. The main symptom is pruritus and it is clinically characterized by the presence of redish-brown papular lesions in the trunk, head and neck. Biopsy of the lesion reveals epidermal invagination with keratotic plug. The etiology is poorly understood and several therapeutic measures have been disappointing.

Keywords: Diabetes mellitus; Kidney failure, chronic; Renal insufficiency, chronic; Skin diseases

Resumo: Dermatose perfurante adquirida é uma condição rara em geral associada a algumas doenças sistêmicas, em especial pacientes diabéticos com insuficiência renal crônica em diálise. O sintoma principal é o prurido e a apresentação clínica característica é a presença de lesões papulares marrom-avermelhadas no tronco, cabeça e pescoço. Biópsia da lesão revela invaginação epidérmica com preenchimento por plug ceratótico. A etiologia é pouco compreendida e várias tentativas terapêuticas tem sido desapontadoras.

Palavras-chave: Dermatopatias; Diabetes mellitus; Falência renal crônica; Insuficiência renal crônica

\section{REFERÊNCES}

Bolognia JL. In: Jorizzo JL, Rapini RP, editors. Dermatology. 2nd ed. Spain: Mosby; 2008.

Chang P, Fernández V. Acquired perforating disease: report of nine cases. Int J Dermatol. 1993;32:874-6. Cordova KB, Oberg TJ, Malik M, Robinson-Bostom L. Dermatologic conditions seen in end-stage renal disease. Semin Dial. 2009:22:45-55

Badziak D, Lenhardt C, Barros MF, Mandelli FL, Serafini SZ, Santamaria JR. Dermatose perfurante adquirida associada à insuficiência hepática em paciente transplantado de fígado. An Bras Dermatol. 2007:82:53-6.

5. Saray Y, Seckin D, Bilezikci B. Acquired perforating dermatosis: clinicopathological features in twenty-two cases. J Eur Acad Dermatol Venereol. 2006;20:679-88.
ENDEREÇO PARA CORRESPONDÊNCIA / MAILING ADDRESS:

Jayme Eduardo Burmeister

Av. Cel. Lucas de Oliveira, 1270 - 301 - Bela Vista

90440-010 - Porto Alegre - RS

E-mail: jb.nefro@gmail.com

Como citar este artigo/How to cite this article: Appel da Silva MC, Miltersteiner DR, Burmeister JE, Zettler CG, Weis L. Caso para diagnóstico. Dermatose perfurante adquirida em paciente com diabetes mellitus e insuficiência renal crônica em hemodiálise. An Bras Dermatol. 2011;86(2):391-440. 